\title{
Analisis Framing Pemberitaan Portal Berita Media Online Mediaindonesia.com dan Beritasatu.com dalam Debat Pilpres Putaran Pertama
}

\author{
Buche Christian Sapulette, Yugih Setyanto, Septia Winduwati \\ Buche.915150085@stu.untar.ac.id,yugihs@gmail.com,septiaw@fikom.untar.ac.id \\ Fakultas Ilmu Komunikasi Universitas Tarumanagara
}

\begin{abstract}
This study discusses the framing analysis conducted by online media news portal Mediaindonesia.com and Beritasatu.com which carried out related news after the first round of the presidential election debate which took place on January 17, 2019. Using the theory analysis framing by Robert N. Entman, seen by Mediaindonesia.com in conducting postdebate reporting it is very disposed and always gives a positive impression on the JokowiAmin pair, and gives a negative impression for the Prabowo-Sandi pair. In contrast to Beritasatu.com which looks more neutral than Mediaindonesia.com, it is still more directed at one side, namely Prabowo-Sandi, but the news does not give a negative impression to the Jokowi-Amin pair.
\end{abstract}

Keywords: Framing Analysis, Mediaindonesia.com, Beritasatu.com, Robert N. Entman, Presidential Election Debate, Jokowi-Amin, Prabowo-Sandi

\begin{abstract}
Abstrak
Penelitian ini meneliti mengenai analisis framing yang dilakukan portal berita media online Mediaindonesia.com dan Beritasatu.com yang melakukan pemberitaan terkait pasca debat putaran pertama pemilihan presiden yang berlangsung pada 17 Januari 2019. Dengan menggunakan teori analisis framing yang dikemukakan oleh Robert N. Entman, terlihat bahwa Mediaindonesia.com dalam melakukan pemberitaan pasca debat tersebut sangat mengarah dan selalu memberikan kesan positif pada pasangan Jokowi-Amin, serta memberikan kesan negatif bagi pasangan Prabowo-Sandi. Berbeda dengan Beritasatu.com yang terlihat lebih netral dibandingkan dengan Mediaindonesia.com, meski tetap lebih mengarah pada satu pihak, yaitu Prabowo-Sandi, namun pemberitaannya tidak ada yang memberikan kesan negatif bagi pasangan Jokowi-Amin.
\end{abstract}

Kata Kunci: Analisis Framing, Mediaindonesia.com, Beritasatu.com, Robert N. Entman, Debat Pilpres, Jokowi-Amin, Prabowo-Sandi

\section{Pendahuluan}

Pada era perkembangan teknologi saat ini, siapa pun dapat menyaksikan atau pun mengetahui segala peristiwa yang terjadi di berbagai belahan dunia melalui berbagai media komunikasi, seperti radio, televisi, surat kabar, media sosial hingga media online dengan mudah serta hal tersebut juga dapat dilakukan di mana pun dan kapan pun. Terlebih kehadiran berbagai portal berita media online, hal tersebut pastinya akan lebih memudahkan masyarakat untuk mengakses segala informasi yang terjadi, dikarenakan kemudahannya yang cukup menggunakan handphone dengan koneksi internet. 
Debat calon presiden dan calon wakil presiden nampaknya merupakan sebuah acara penting yang patut disaksikan bagi seluruh kalangan masyarakat, terlebih bagi mereka yang sudah memiliki hak untuk menyalurkan suaranya. Debat pertama yang berlangsung pada tanggal 17 Januari 2019 tersebut dapat menunjukkan bagaimana kualitas dari pasangan calon yang mencalonkan dirinya sebagai pemimpin negara ini dan dapat pula dijadikan tolok ukur masyarakat dalam menentukan pilihannya pada 17 April 2019 mendatang. Segala hal yang terjadi dan disampaikan oleh masing-masing pasangan calon pada debat berlangsung pastinya tidak akan luput dari yang namanya media. Seperti yang kita ketahui saat ini media sering dikatakan sebagai pilar ke-4 yang mengawasi segala kegiatan yang terjadi di negeri ini, selain itu media juga merupakan menjadi salah satu sumber informasi utama bagi masyarakat luas. Maka dari itu media pastinya akan menerbitkan banyak pemberitaan yang membahas mengenai debat pertama antara masing-masing calon presiden dan calon wakil presiden tersebut. Terlebih saat ini portal berita media online yang sangat mengutamakan kecepatan dalam melakukan penyebaran informasinya. Media yang merupakan sumber informasi bagi masyarakat diharapkan dapat bertindak sebagaimana mestinya tanpa adanya intervensi maupun kepentingan dari pihak manapun. Media sebagai pilar ke-4 diharapkan dapat bertindak senetral mungkin dalam menyebarkan informasi kepada masyarakat.Dengan berkembangnya media online saat ini, serta berbagai latar belakang dari masing-masing pemilik media tersebut.

Pada penelitian ini penulis memilih portal berita mediaonline Mediaindonesia(dot)com dan portal berita mediaonline Beritasatu(dot)com. Pemilihan kedua media tersebut pun didasarkan latar belakang dari kepemilikan masing-masing media tersebut. Mediaindonesia(dot)com yang didirikan oleh Teuku Yousli Syah sejak tahun 1970, kemudian bergandeng tangan dengan Surya Paloh pada tahun 1987 dan berada di bawah naungan PT. Citra Media Nusa Purnama dengan motto "Jujur Bersama" sejak tahun 2010. Seperti yang diketahui saat ini Surya Paloh selain memiliki berbagai media, seperti Metro TV dan portal berita Mediaindonesia(dot)com yang berada dalam kelompok usaha Media Group, Surya Paloh merupakan ketua umum dari Partai Nasional Demokrat (NasDem). Partai NasDem sendiri merupakan pihak koalisi dari pemerintahan Joko Widodo saat ini, yang juga merupakan salah satu calon presiden pada pemilihan presiden mendatang.

Sedangkan Beritasatu(dot)com didirikan oleh BeritaSatu Media yang sebelumnya bernama Globe Media Group, dan perusahaan ini merupakan bagian dari Lippo Group. Berada di dalam Lippo Group yang dikenal dengan sebuah perusahaan besar di Indonesia yang bergerak diberbagi bidang bisnis seperti properti hingga restoran, namun saat ini menjalani sebuah media portal berita Beritasatu(dot)com yang memiliki motto "The Chanel for Decision Makers".

Atas dasar pertimbangan ini, penulis bertujuan untuk memahami, menganalisis dan membandingkan kedua media tersebut, yaitu Mediaindonesia(dot)com dan Beritasatu(dot)com dalam bagaimana kedua media ini melakukan pemberitaan yang membahas mengenai debat masing-masing calon presiden dan calon wakil presiden pada putaran pertama 17 Januari 2019. Analisis ini dilakukan untuk mengetahui bagaimana media-media tersebut dalam membuat realitas menggunakan metode framing. 


\section{Kerangka Pemikiran}

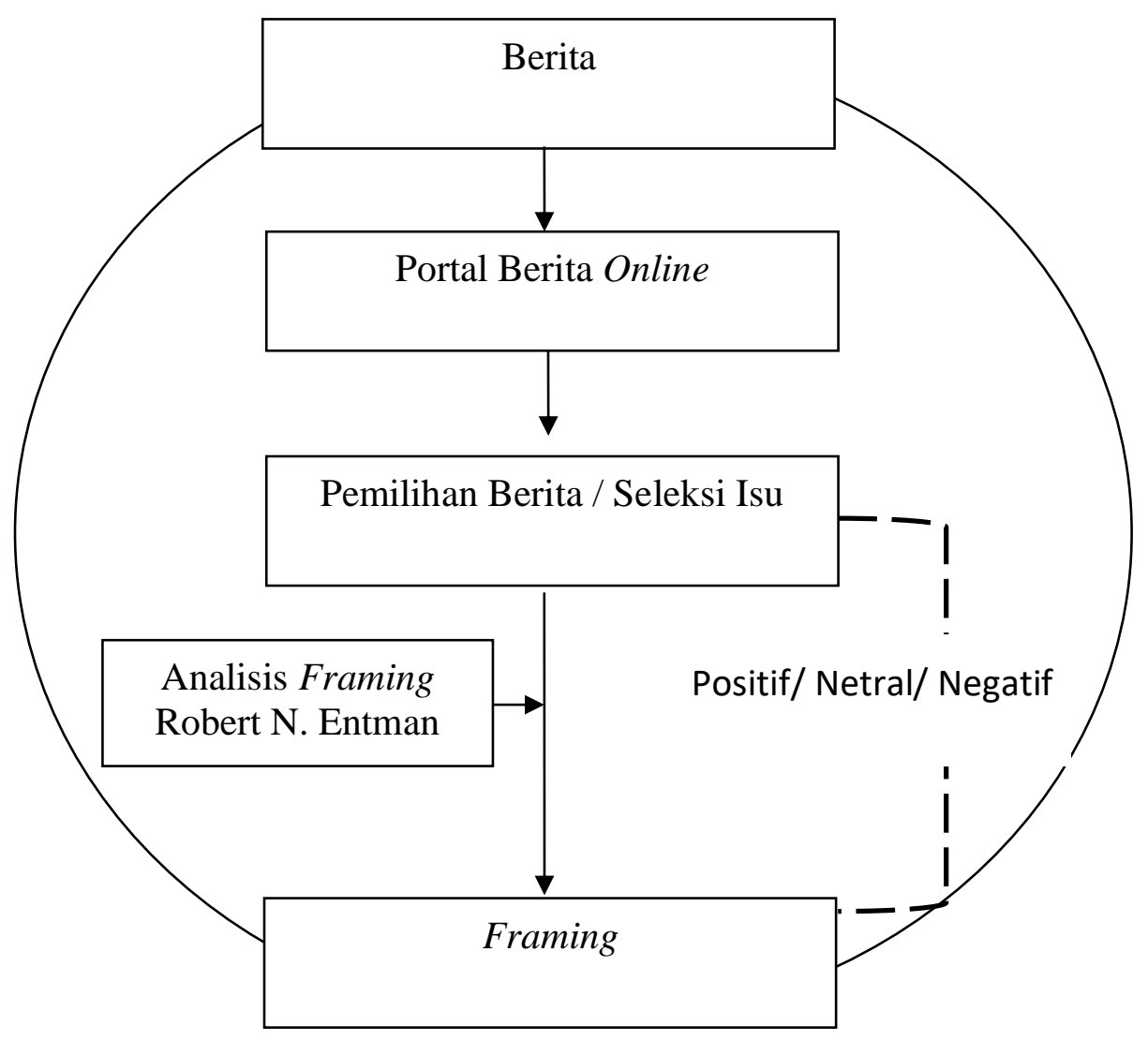

(Sumber : Hasil Olahan Pribadi)

Debat yang dilakukan oleh masing-masing pasangan calon pada putaran pertama yang berlangsung pada tanggal 17 Januari 2019 sampai 16 Februari 2019, tentunya tidak akan luput dari liputan media. Dalam menyampaikannya media akan mengemasnya dengan sedimikian rupa, seperti hanya menekankan satu isu tertentu dan mengabaikan isu lainnya. Meskipun mengusung satu topik yang sama, namun masing-masing media bisa saja menyampaikan informasi yang berbeda. Hal itu tergantung bagaimana wartawan tersebut membingkai suatu kejadian ataupun bisa disebabkan adanya kepentingan tertentu. Dalam konsepsi framing Entman, pada dasarnya merujuk pada pemberian definisi, penjelasan, evaluasi, dan rekomendasi dalam suatu wacana untuk menekankan kerangka berpikir tertentu terhadap peristiwa yang direncanakan. Lebih lanjut, untuk menggambarkan secara luas bagaimana peristiwa dimaknai dan ditandakan oleh wartawan. Define problems. Elemen ini merupakan bingkai yang paling utama dan menekankan bagaimana peristiwa dipahami oleh wartawan. Ketika ada masalah atau peristiwa, bagimana peristiwa atau isu tersebut dipahami. Peristiwa yang sama dapat dipahami secara berbeda. Dan bingkai yang berbeda ini akan menyebabkan realitas bentukan yang berbeda. Diagnose causes Penyebab di sini bisa berati apa (what), tetapi bisa juga berarti siapa (who). Make moral judgement Gagasan yang dikutip berhubungan dengan sesuatu yang familiar dan dikenal oleh khalayak. Elemen framing lain adalah treatmentrecommendation (menekankan penyelesaian). Elemen ini dapat dipakai untuk menilai apa yang 
dikehendaki oleh wartawan serta jalan apa yang dipilih untuk menyelesaikan masalah. Tentu saja hal ini sangat tergantung pada bagaimana peristiwa itu dilihat dan siapa yang dipandang sebagai penyebab masalah.Oleh sebab itu, dengan menggunakan analisis framing, peneliti ingin melihat beberapa kemungkinan yang dapat terjadi seperti potensi berita bermuatan positif, netral maupun negatif terhadap pemberitaan mengenai debat pilpres putaran pertama yang diselenggarakan pada 17 Januari 2019 sampai 16 Februari 2019.

\section{Metode Penelitian}

Jenis penelitian ini menggunakan pendekatan kualitatif yang bersifat deskriptif. Penggunaan pendekatan kualitatif yang bersifat deskritptif bertujuan untuk menggambarkan, meringkaskan berbagai kondisi, berbagai situasi, atau berbagai fenomena realitas sosial yang ada di masyarakat yang menjadi objek penelitian, dan berupaya menarik realitas itu ke permukaan sebagai suatu ciri, karakter, sifat, model, tanda, atau gambaran tentang kondisi, situasi, ataupun fenomena tertentu (Bungin, 2011 : 68). Realitas sosial yang ingin digambarkan oleh peneliti ialah bagaimana masing-masing dari portal berita online Mediaindonesia(dot)com dan Beritasatu(dot)com dalam melakukan pembingkaian berita mengenai debat masingmasing calon presiden dan calon wakil presiden pada putaran pertama 17 Januari 2019. Untuk mengetahui pembingkaian yang dilakukan Peneliti menggunakan strategi penelitian analisis framing yang dikemukakan oleh Robert N. Entman, yang terdapat 4 perangkat yang digunakan untuk melakukan analisis, yaitu: define problems (pendefinisian masalah), diagnose causes (memperkirakan masalah/sumber masalah), make moral judgement (membuat keputusan moral), dan treatment recommendation (menekankan penyelesaian) (Eriyanto, 2011). Analisis framing digunakan untuk membedah cara-cara atau ideologi media saat mengkonstruksikan fakta. Analisis ini mencermati strategi seleksi, penonjolan, dan tautan fakta ke dalam berita agar lebih bermakna, lebih menarik, lebih berarti atau lebih diingat, untuk menggiring interpretasi khalayak sesuai perspektifnya (Sobur, 2006 : 162).

Subyek dalam penelitian ini ialah portal berita media online Mediaindonesia(dot)com dan Beritasatu(dot)com, sedangkan obyeknya ialah artikelartikel berita yang membahas mengenai debat calon presiden dan calon wakil presiden pada putaran pertama yang berlangsung tanggal 17 Januari 2019 sampai 16 Februari 2019, yang ditampilkan oleh portal berita online Mediaindonesia(dot)com dan Beritasatu(dot)com.

Dalam melakukan pengumpulan data, Peneliti menggunakan artikel-artikel berita yang ditampilkan oleh Mediaindonesia(dot)com dan Beritasatu(dot)com, kemudian Peneliti juga melakukan wawancara dan studi pustaka.

Kemudian untuk analisis data menggunakan Miles dan Huberman. 


\section{Hasil Temuan dan Diskusi}

Tabel 1. Hasil Temuan Pada Mediaindonesia.com

\begin{tabular}{|c|c|c|c|}
\hline No & Judul Berita & & Hasil Temuan \\
\hline \multirow[t]{2}{*}{1} & Prabowo & Dinilai & Jerry $\quad$ Massie berpendapat \\
\hline & Inkonsisten Soal Korup & & Prabowo Subianto inkonsistensi. \\
\hline 2 & $\begin{array}{lll}\text { Lebih } & \text { Memahami } \\
\text { Masalah } & \text { di } & \text { Debat } \\
\text { Pertama } & & \end{array}$ & $\begin{array}{r}\text { Peta } \\
\text { Putaran }\end{array}$ & $\begin{array}{l}\text { TGB menilai Capres } 01 \text { lebih } \\
\text { memahami masalah dibandingkan } \\
\text { Capres 02. }\end{array}$ \\
\hline
\end{tabular}

3 Lebih Banyak Respons Positif Pasca Debat

TKN Jokowi-Amin mengaku paslonnya lebih unggul.

\begin{tabular}{|c|c|c|c|}
\hline 4 & $\begin{array}{l}\text { Permasalahkan } \\
\text { Pemberian } \\
\text { Pertanyaan Debat }\end{array}$ & $\begin{array}{r}\text { Soal } \\
\text { Kisi-Kisi }\end{array}$ & $\begin{array}{l}\quad \text { Jubir } \quad \text { TKN } \quad \text { tidak } \\
\text { mempermasalahkan ada/tidaknya kisi- } \\
\text { kisi. }\end{array}$ \\
\hline 5 & $\begin{array}{l}\text { Jokowi-Amin } \\
\text { Prabowo-Sandi }\end{array}$ & Ungguli & $\begin{array}{l}\text { Jokowi-Amin lebih unggul } \\
\text { dalam menyampaikan pendapat, } \\
\text { menyanggah dan berargumentasi. }\end{array}$ \\
\hline
\end{tabular}

Tabel 2. Hasil Temuan Pada Beritasatu.com

\begin{tabular}{|c|c|c|}
\hline No. & Judul Berita & Temuan \\
\hline 1. & $\begin{array}{l}\quad \text { Prabowo Tidak } \\
\text { Persoalkan Mantan } \\
\text { Koruptor Maju di Pileg } \\
2019\end{array}$ & $\begin{array}{l}\text { Prabowo Subianto menegaskan } \\
\text { dan membenarkan ucapannya sendiri } \\
\text { pada debat pilihan presiden putaran } \\
\text { pertama. }\end{array}$ \\
\hline 2. & $\begin{array}{l}\quad \text { BPN Menilai Gaya } \\
\text { Prabowo di Debat Perdana } \\
\text { Kurang Buat Gereget }\end{array}$ & $\begin{array}{l}\text { Andre Rosiade menilai dan } \\
\text { membenarkan gaya debat capres nomor } \\
\text { urut } 02 \text { Prabowo Subianto. }\end{array}$ \\
\hline 3. & $\begin{array}{l}\quad \text { Kritik Aturan Debat, } \\
\text { Sudirman Said: KPU Harus } \\
\text { Seperti Panitia Pernikahan }\end{array}$ & $\begin{array}{l}\text { Sudirman Said membela Prabowo } \\
\text { dalam hal aturan debat pilihan presiden. }\end{array}$ \\
\hline 4. & $\begin{array}{l}\text { KPU Tak Berikan } \\
\text { Lagi Kisi-Kisi di Debat } \\
\text { Kedua Capres } 2019\end{array}$ & $\begin{array}{l}\text { Wahyu Setiawan menegaskan } \\
\text { kisi-kisi pertanyaan tidak akan lagi } \\
\text { diberikan. }\end{array}$ \\
\hline 5. & $\begin{array}{l}\text { Gerindra Optimistis } \\
\text { Suara Swing Voters untuk } \\
\text { Prabowo-Sandi }\end{array}$ & $\begin{array}{c}\text { Rahayu } \\
\text { Saraswati } \\
\text { pasangan Prabowo-Sandi. }\end{array}$ \\
\hline
\end{tabular}

Melalui hasil analisis yang di lakukan dengan menggunakan 4 perangkat framing Robert N. Entman, penulis akan melakukan pembahasan dari masing-masing hasil analisis yang sudah dilakukan sebelumnya terlihat adanya perbedaan dalam penyampaian pemberitaan oleh Mediaindonesia(dot)com dan Beritasatu(dot)com.

Mediaindonesia(dot)com dalam penyampaiannya terlihat cukup jelas bahwa Mediaindonesia berpotensi ke arah tidak netral dalam melakukan pemberitaan yang 
membahas mengenai pasca debat pilpres putaran pertama yang berlangsung pada 17 Januari 2019. Mediaindonesia memberikan dukungannya pada pasangan JokowiAmin, hal itu terlihat dari kelima pemberitaan yang ditampilkan oleh Mediaindonesia dan sudah dianalisis dengan menggunakan 4 perangkat framing Robert N. Entman, meski narasumbernya tidak seluruhnya berasal dari pihak pendukung Jokowi-Amin, namun seluruh pesan yang berada dalam masing-masing berita tersebut memberikan pesan yang positif dan terdapat juga kritikan pedas yang ditunjukan bagi pasangan calon 02. Meskipun ada narasumber yang tidak berasal dari pihak pendukung JokowiAmin. Isi dari berita tersebutpun tetap memberikan kesan positif bagi pasangan 01, hal inipun juga disampaikan oleh narasumber saya, yang mengatakan bahwa wartawan akan memasukan kutipan dari pakar ataupun pihak lain dan seperti membenarkan pakar tersebut, dan dia juga sependapat, mengatakan bahwa Mediaindonesia merupakan media partisan dan memberikan kesan negatif bagi pasangan PrabowoSandi.

Kemudian, berbeda dengan berita-berita yang ditampilkan oleh Beritasatu(dot)com, meski juga cukup berkesan mengarah pada satu pihak, yaitu Prabowo-Sandi, pada Beritasatu tidak ditemukannya pemberitaan yang memberikan kritikan pedas ataupun pesan negatif yang ditunjukan pada pihak lawan. Narasumbernya juga hampir sama dengan Mediaindonesia, tidak seluruhnya merupakan pihak pendukung pasangan 02, tetapi juga terdapat dari pihak KPU yang menjadi narasumber beritanya. Pihak KPU yang menjadi narasumber dalam pemberitaan itu juga tidak memberikan pesan yang mengandung pesan-pesan yang dapat menggiring opini pembaca, namun lebih bersifat informatif. Berbeda dengan yang ditampilkan oleh Mediaindonesia, meski narasumbernya berasal dari pihak luar, namun isi dari pemberitaannya tetap memberikan pesan positif bagi paslon 01 . Berdasarkan hasil wawancara peneliti dengan pengamat media, beliau berkata bahwa Beritasatu mulai cukup netral, berbeda pada saat 2014 yang sangat mendukung pasangan Jokowi. Namun, nampaknya Beritasatu melakukan framing yang soft dan berpotensi netral.

\section{Kesimpulan}

Mediaindonesia(dot)com seperti memberikan dukungannya untuk pasangan calon Jokowi-Amin. Mediaindonesia juga membingkai bahwa seluruhnya pemberitaan yang ditampilkan merupakan pemberitaan yang positif bagi pasangan Jokowi-Amin, itu semua terlihat dari narasumber yang dipilih. Narasumber yang terkait didalam setiap pemberitaan berasal dari partai yang mendukung pasangan Jokowi-Amin serta beberapa narasumber ahli yang berasal dari lembaga-lembaga survei atau dalam kata lain orang-orang dari non partai yang bersifat netral.

Beritasatu(dot)com dalam membingkainya lebih mengarah pada pihak PrabowoSandi,serta cukup netral dan tidak terlalu menyudutkan pihak manapun. Beritasatu(dot)com juga menampilkan pemberitaan yang berkesan membangun sebuah citra-citra positif untuk pasangan Prabowo-Sandi di masyarakat, dengan menampilkan gaya-gaya komunikasi kekinian dan sikap positif atau percaya diri dengan memperlihatkan perbedaan yang dimiliki oleh pasangan Prabowo-Sandi dengan pasangan Jokowi-Amin, walaupun tetap dalam pemilihan narasumber yang memperlihatkan keterlibatan orang dari partai pendukung Prabowo-Sandi.

Kemudian dari keseluruhan pemberitaan yang dilakukan oleh ke-2 media tersebut ditemukan perbedaan diantara masing-masing media, dikarenakan ke-2 media 
ini nyatanya cenderung mendukung masing-masing dari para calon presiden dalam pemilihan umum 2019. Perbedaan terlihat dalam pemilihan narasumbernya. Mediaindonesia dalam pemilihan narasumbernya berasal dari pihak-pihak yang berada dalam koalisi petahana dan non partai, sedangkan Beritasatu berasal dari pihak oposisi.

Kemudian pemilik media yang terlibat dalam partai politik akan memberikan dampak pada isi beritanya. Mediaindonesia memberitakan pemberitaan yang mengarah untuk mendukung, karena berada dalam koalisi petahana dalam pemilihan umum presiden 2019, berbeda dengan Beritasatu yang tidak secara langsung mendukung kebijakan pemerintahan dan mendukung oposisi untuk kepentingan pribadi.

\section{Ucapan Terima Kasih}

Ucapan terima kepada Bapak Yons Achmad, sudah meluangkan waktunya dan berbagi informasi untuk menjadi narasumber dalam penelitian ini.

\section{Daftar Pustaka}

Bungin, Burhan. (2011). Penelitian Kualitatif. Jakarta: Kencana Predana Media Group.

Eriyanto. (2011). Analisis Framing: Konstruksi, Ideologi, dan Politik Media. Yogyakarta: LkiS.

Miles, Mattew B dan Amichael Huberman. (2007). Analisis Data Kualitatif Buku Sumber tentang Metode-Metode Baru. (Tjetjep Rohendi Rohisi, Penerjemah). Jakarta: Universitas Indonesia

Sobur, Alex. (2006). Semiotika Komunikasi. Bandung: Remaja Rosdakarya. 